\title{
OMAA TYÖTÄ MUOTOILEMASSA - TYÖNTEKIJÄT TIETEELLISEN KIRJASTON MUUTOKSESSA
}

Tieteellisten kirjastojen työn painopiste on muuttunut yksittäisten kokoelmien hallinnasta aineistojen saatavuuden varmistamiseen ja palveluiden vaikutusten arviointiin sekä tieteellisen julkaisemisen ja näkyvyyden tukemiseen. Työn muutokseen ovat vaikuttaneet jo pidemmän aikaa avoin tiede ja uusien teknologioiden kehitykset. Suurin muutos tapahtui reilu vuosi sitten, kun pandemia pakotti yhteiskunnat digiloikkaan nopeassa ajassa. Tieteellisten kirjastojen palvelut muotoiltiin poikkeusoloihin sopiviksi, mutta myös työntekijät joutuivat miettimään uusiksi tavat tehdä töitä.

$\mathrm{T}$ ein YAMK-opinnäytetyön Turun ammattikorkeakoulun liiketoiminnan kehittämisen koulutusohjelmaan. Tutkimusaihe syntyi tarpeesta tutkia työntekijää tieteellisen kirjaston nopeissa muutoksissa. Työntekijän on löydettävä näissä muutoksissa itselleen sopivia keinoja kehittää työtään toiminnan tavoitteiden saavuttamiseksi. Työn muotoilu valikoitui tutkimuksen kohteeksi, koska siinä tarkastellaan työelämän myönteisiä ilmiöitä, kuten työn hallintaan, voimavaroihin ja motivaatioon liittyviä tekijöitä. Tutkimuksessa keskityttiin kolmen muutosajurin - avoimen tieteen, uusien teknologioiden ja pandemian - vaikutuksiin tieteellisten kirjastojen työssä. (Kähö 202I.)

\section{Avoin tiede vaikuttaa monin tavoin}

Tutkimus oli monimenetelmällinen ja siinä yhdistettiin määrällistä ja laadul- lista tutkimusta. Nykytilan analyysiin käytettiin määrällisen tutkimuksen menetelmää ja tilastot poimittiin Suomen tieteellisten kirjastojen yhteistilastotietokannasta (КІтT) vuosilta 20 I 22019. Toimintaympäristön muutosta tarkasteltiin Suomen tieteellisissä kirjastoissa kokoelmarakenteen, käytön ja henkilöstörakenteen avulla. Painettujen aineistojen osuus kokoelmissa on vähentynyt I $4 \%$ ja elektronisten aineistot kasvanut $70 \%$ tarkastelujakson aikana. Lainamäärät palvelutiskillä ja itsepalveluautomaateilla ovat laskeneet $48 \%$. Tieteellisten kirjastojen henkilömärät ovat laskeneet yhteensä $36 \%$ vuosien 20 I 2 ja 20 I 9 välillä. (Kähö 202I.)

Laadullisen tutkimuksen menetelmä oli teemahaastattelu ja haastatteluun osallistui neljä tieteellisen kirjastojen asiantuntijaa, joiden tehtävä on varmistaa laadukkaat ja aktiivisesti käytettävät aineistot tutkimuksen, 
"Asiat muuttuvat koko ajan - ei ainoastaan kirjastoalalla, vaan kaikkialla.

Ei ole päivää, ettei tulisi uutta työpöydälle ja täytyy miettiä päivittäin, mikä on olennaista tehdä tänään. Työ ei ole yksitoikkoista, vaan haaste on, ettei tule liikaa kerralla."

- Haastateltava Kähön (2021) opinnäytetyössä

opetuksen ja oppimisen tarpeisiin. Tutkimuksen ulkopuolelle rajattiin esimiestyö. (Kähö 202г.)

Tutkimuksessa viitataan monipaikkaiseen työhön, jolla tarkoitetaan työskentelyä useassa eri paikassa päätyöpaikan lisäksi. Monipaikkaisessa työssä hyödynnetään sähköisiä viestintävälineitä, joita työntekijä kuljettaa mukanaan työskennellessään useassa eri työpisteessä tarpeen mukaan. Vaikka tietotekniikkaan perustuva monipaikkainen työ mahdollistaa uudenlaisia työkäytäntöjä, on tärkeä huomioida, että työntekijän tulee hallita uudella tavalla työnsä lisäksi myös modernia toimintaympäristöä. (Hyrkkänen \& Vartiainen 2019.) Onnistunut monipaikkainen työ edellyttää organisaatiolta matalaa hierarkiaa ja työntekijöiltä yhdessä ohjautuvuutta (Harju-Myllyaho, et al. 2019).

Tutkimuksessa mainituista muutosajureista avoin tiede ja uusien teknologioiden kehitys ovat vaikuttaneet jo pidemmän aikaa tieteellisten kirjastojen työhön. Avoimen tieteen vaikutus muuttaa paitsi tieteellisen kirjaston ra- kenteita, tehtäviä ja osaamista, myös ajatusta kirjastokokoelmasta. OECD:n mukaan tieteelliset kirjastot ovatkin ottaneet aktiivisen roolin niin tutkimusaineistojen kuin tutkimusjulkaisujen ja -datan saatavuuteen, säilytykseen ja näkyvyyteen liittyvissä asioissa. Kirjastot neuvovat ja antavat tukea avoimeen tieteen ja julkaisuihin liittyvissä asioissa. Kirjastot muodostavat fyysisen infrastruktuurin, jonka avulla tiedeyhteisö voi luotettavasti jakaa ja hyödyntää tutkimustyön tuloksia. Nämä tekijät ovat välttämättömiä avoimen tieteen edistymisessä. (OECD 201 5.)

\section{Mitä tarkoittaa työn muotoilu?}

$\mathrm{T}$ yön muotoilu (job crafting) on työntekijän keino hallita työnsä vaatimuksia sekä omia ja työnsä voimavaroja. Työn muotoilussa työntekijä muokkaa paitsi työympäristöään, myös työn sisältöjä, toimintatapoja ja sosiaalisia suhteita sekä kognitiivisia tarpeita vastaamaan omia arvoja, vahvuuksia, osaamista ja tarpeita. (Parker \& Ohly 2008.) Pyrkimyksenä on, että työntekijä hallitsee työn muotoilun avulla työn vaatimuksia ja voimavaroja. Yksilö, tiimi ja organisaatio yhdessä hyötyvät, kun työssään viihtyvät ja tyytyväiset työntekijät ovat sitoutuneita tavoitteisiin, suoriutuvat hyvin tuloksin ja ovat motivoituneita kehittämään työyhteisöä. (Tims \& Bakker \& Derks 20I 2; Wrzesniewski \& LoBuglio \& Dutton \& Berg 2013.)

Työn muotoilu sisältää myös it- 
seohjautuvuuden näkökulman ja sen kehittäminen on tärkeää, koska työtä tehdään sekä yksin että yhdessä monipaikkaisesti, yhtä aikaa monesta eri paikasta. (Harju-Myllyaho, et. al. 20I9.) Työilmapiirin ja lähijohtamisen tärkeys korostuvat, koska onnistumisen kannalta on oleellista löytää sujuva vuorovaikutus sekä saada palaute tehdystä työstä. Samalla on mahdollistettava keskittymisrauhaa sovittujen asioiden tekemiseen. (Hyrkkänen \& Vartiainen 2019.)

On hyvä kuitenkin pitää mielessä, että työelämässä ei voi vain yksipuolisesti päättää, keiden kanssa tekee töitä, mitä tehtäviä suorittaa tai mitä uutta haluaa oppia. Työn muotoilun kannalta onkin oleellista oppia tunnistamaan oman työn tapoihin vaikuttavat tekijät. Tämän avulla voi oppia vaikuttamaan työn eri laatutekijöihin ja sitä kautta myös koko työyhteisöön.

\section{Työn vaatimukset kasvavat muutoksessa}

Kun toimintaympäristö muuttuu, työn vaatimukset useimmiten kasvavat. Muutoksen vauhti voi olla nopeaa, mutta ihmisessä tapahtuva muutos ei yleensä ole. Tutkimuksessa hyödynnettiin työn vaatimukset ja voimavarat (TV-TV)-mallia, joka on yksi teoreettisista kehyksistä, joilla työn muotoilua voidaan tarkastella. TV-TV-mallin perusajatuksena on, että työn ominaisuudet voidaan jakaa organisaatiosta ja tehtävästä riippumatta kahteen yleiseen kategoriaan: työn vaatimukset (job demands) ja työn voimavarat (job resources) (Bakker et al. 2003).

Työn vaatimukset ikään kuin maksavat jotakin. Kiire, työtehtävien paljous ja heikko työilmapiiri ovat esimerkkejä vaatimuksista. (Bakker et al. 2003; Bakker \& Demerouti 2007; Kärnä 20I9.) Hyrkkänen ja Vartiainen (2019) ovat aiemmissa tutkimuksissaan tunnistaneet mobiiliin työn vaativuustekijöitä: matkustaminen, monipaikkainen työskentely, uudella tavalla rakentuva työaika, projektimainen työtapa, välittynyt vuorovaikutus ja yhteistyö sekä erilaisissa kulttuureissa toiminen.

Työn voimavaroilla tarkoitetaan positiivisten kokemusten vahvistamista ja niitä työn ominaisuuksia, jotka voivat auttaa saavuttamaan työn tavoitteet. Työn voimavarat vähentävät työn vaatimuksia ja niihin liittyviä fysiologisia ja psykologisia kustannuksia sekä innostavat henkilökohtaiseen kasvuun ja kehittymiseen. Työn voimavaroja voi olla esimerkiksi organisaation tarjoamat uramahdollisuudet ja kouluttautuminen, osallistuminen päätöksentekoon, työyhteisön antama tuki, hyvä työilmapiiri, toimiva

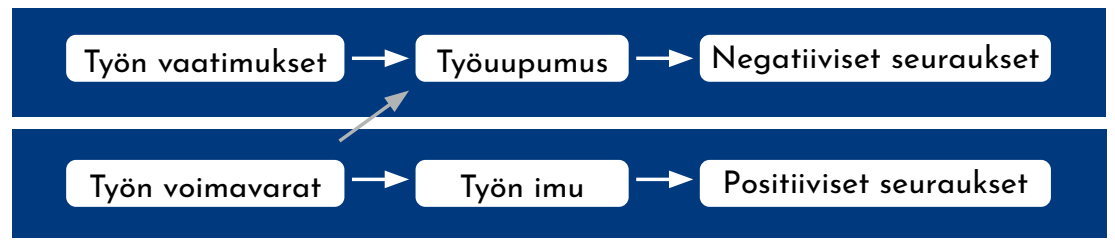

Työn vaatimukset - työn voimavarat (TV-TV)-malli (Bakker et al. 2003; Schaufeli 2017; Kärnä 2019). 
yhteistyö esimiehen kanssa, tehtävän ja osaamisen monipuolisuus, työn itsenäisyys. Voimavarat auttavat saavuttamaan työlle asetut tavoitteet ja niillä pyritään ehkäisemään työn vaatimusten negatiivisia vaikutuksia. (Bakker et al. 2003; Bakker \& Demerouti 2007; Kärnä 20I9.)

\section{Asiakaspalvelutyö on tärkeä voimavara}

Asiantuntijoiden teemahaastattelussa nousi vahvasti esiin kiire ja sen tuomat vaatimukset työhön. Haastatteluista kävi ilmi, että aikaa ei tunnu olevan riittävästi työn suunnittelulle ja arvioinnille kiireen keskellä. Haastatteluiden temaattisissa sisällönanalyyseissa havaittiin viisi pääteemaa. Muutoksen vaikutus esiintyi kaikissa teemoissa, jotka olivat

- avoin tiede

- kirjaston palvelut

- kokemus työstä

- vuorovaikutus

- työvälineet.

Vahvimmat työn vaatimukset teemahaastattelujen perusteella olivat kiire ja työkuorma eli miten hallita työtehtäviä kiireessä: "töitä täytyy priorisoida ja kaikkea ei ehdi tekemään, vaikka haluaisikin”. Vaatimuksissa nousi esiin myös uudet tehtävät, jotka ajoittain koettiin ikään kuin hiipivän nykyisten työtehtävien rinnalla. Työn hallinnan tunne on tässä tapauksessa vaarassa vähentyä, jos nykyisiä työtehtäviä ja käydä läpi uusien työtehtävien lisääntyessä. Näissä tapauksissa olisi tärkeää käydä läpi työn muotoilun avulla hallintatapojen lisäksi työn sisältöjä, toimintatapoja sekä sosiaalisia suhteita.

Työn voimavaroissa nousi esiin asiakaspalvelutyön tärkeys ja siinä saatu suora palaute omalle työlle. Asiakaspalvelutyössä voimavaraksi nousi kohtaamiset asiakkaan kanssa ja se, kun pystyi neuvomaan asiakasta ongelman edessä. Lisäksi sujuva yhteistyö työyhteisössä on työn voimavaroihin vaikuttava tekijä, samoin kuin tehtävien monipuolisuus.

Teemahaastatteluissa nousi kokemuksina esiin huolestumista ja jopa stressaantumista. Sen sijaan työn hallinnan ja rentoutumisen kokemuksia ei havaittu teemahaastatteluissa. Epävarmuus esimerkiksi avoimen tieteen aiheuttamista aineistokustannusten noususta mietitytti. Uusien teknisten työvälineiden kehitys aiheutti hallitsemattomuuden tunteita, kun aika ei riitä niiden tutustumiseen ja oppimiseen. Työyhteisön tukea pidettiin tärkeää ja sitä tarvittaisiin vielä enemmänkin,

\begin{tabular}{|c|c|}
\hline Työn vaatimukset & Työn voimavarat \\
\hline $\begin{array}{l}\text { - kiire } \\
\text { - uudet työvälineet } \\
\text { - työkuorma; paljon töitä hallittavana } \\
\text { - uudet tehtävät }\end{array}$ & $\begin{array}{l}\text { - asiakaspalvelutyö } \\
\text { - palaute } \\
\text { - tehtävien monipuolisuus } \\
\text { - sujuva yhteistyö }\end{array}$ \\
\hline
\end{tabular}

Tieteellisen kirjastotyön vaatimukset ja voimavarat 
koska on paljon sellaista, mitä joutuu ihmettelemään yksin.

Välittyneen vuorovaikutuksen tärkeys nousi esiin myös teemahaastetteluissa. Sujuva vuorovaikutus on paitsi monen asian summa, myös tärkeä osa työn sujuvuuden ja tavoitteiden saavuttamisen kannalta. Vuorovaikutusta voidaan parantaa esimerkiksi tutustumalla toisen yksikön työhön tai tarkkailemalla muiden tapoja tehdä työtä. Omaa työtä voi esitellä myös monin eri tavoin, kuten kirjoittamalla blogia, tekemällä esittelyvideon tai podcastin. Yhtenä hyvänä esimerkkinä oman työn muotoilussa on uuden taidon opettelu. Se myös lisää työn hallinnan tunnetta. Rikkomalla rutiineja voi myös saada uusia näkökulmia omaan työhönsä.

\section{Lopuksi}

Tieteellisen kirjastonhoitajan työ perustuu yhä enemmän työskentelyyn monipaikkaisessa toimintaympäristössä, jolloin vuorovaikutus perustuu välitty- vän yhteistyöhön eli fyysisiä tapaamisia ei ole entiseen tapaan. On tärkeää muotoilla työaikaa uudella tavalla, huomioida erilaisissa toimintakulttuureissa työskentelyä sekä miettiä, miten yhteistyö ja vuorovaikutus toimivat monipaikkaisessa toimintaympäristössä.

jälle paitsi keinoja hallita työn vaatimuksia, se myös auttaa tunnistamaan oman työn voimavaroja. Parhaimmillaan työn muotoilu tarjoaa hyvän kierteen ja yleensä se ei lopu vain yhteen kokemukseen, vaan uusia haasteita ja uudistuksia työssä ja työyhteisössä halutaan hakea yhä uudelleen. Tämä kaikki auttaa työntekijää kehittymään taitavaksi tekijäksi hyödyntäen eri kehittämismahdollisuuksia omalla työurallaan. Työyhteisöt, joiden työntekijät muotoilevat työtään, ovat onnekkaita, koska tarmokkaat, keskittymiskykyiset sekä ammatillisesti sitoutuneet työntekijät tuovat myös parhaan tuloksen työyhteisölle.

\section{Lähteet}

Bakker, A.B. \& Demerouti, E., 2007. The Job Demands-Resources model: state of the art, Journal of Managerial Psychology, 22(3), 309-328. Viitattu: I 5. I. 202 I. https://doi. org/I0.I I08/02683940710733 II

Bakker, A.B., Demerouti, E., de Boer, E. \& Schaufeli, W. B., 2003. Job demands and job resources as predictors of absence duration and frequency. Journal of vocational behavior, 62(2), 34I-356. Viitattu: I 5. I. 202I. https://doi.org/Io. Io I6/Sooo I$879 \mathrm{I}(\mathrm{O} 2) 00030-\mathrm{I}$

Harju-Myllyaho, A., Jussila, M., Puro A. \& Sipponen, M., 2019. Etäisyyksien hallintaa monipaikkaisessa ja mobiilissa työssä. Teoksessa M. Roininen. (toim.) Työn muotoilu mobiilissa ja monipaikkaisessa työssä. Turun ammattikorkeakoulun raportteja 26I. Turku: Turun ammattikorkeakoulu, 39-44. Viitattu I I. 2.202 I. http://julkaisut.turkuamk.fi/ isbn9789522167408.pdf 
Hyrkkänen, U. \& VArtiainen, M., 20I9. Mobiilin ja monipaikkaisen työn muotoilu. Teoksessa M. Roininen. (toim.) Työn muotoilu mobiilissa ja monipaikkaisessa työssä. Turun ammattikorkeakoulun raportteja 26I. Turku: Turun ammattikorkeakoulu, I I-I 8 . Viitattu 7.2.2021. http://julkaisut.turkuamk.fi/isbn9789522167408.pdf

Кёнӧ, E., 202 I. Tuunaa työtä - työntekijät tieteellisen kirjaston muutoksessa.

Opinnäytetyö. YAMK, liiketoiminnan kehittäminen. Turku: Turun ammattikorkeakoulu. Viitattu 9. 5.202I. http://urn.fi/URN:NBN:fi:amk-202104094505

KäRNÄ, J., 20I9. Vaikuttaako persoonallisuus lääkäreiden työn imun, työn tuunaamisen ja hyvinvoinnin välisiin yhteyksiin? Pro gradu-tutkielma. Helsingin yliopisto, läketieteellinen tiedekunta. Viitattu 22. I. 202 I. http://urn.fi/ URN:NBN:fi:hulib-201910163686

OECD 2015 . Making Open Science a Reality. OECD Science, Technology and Industry Policy Papers, No. 25, Paris: OeCD Publishing. Viitattu 22. I. 202 I. http://dx.doi. org/I0.1787/5jrs2f963zsi-en

Parker, S. \& Ohly, S., 2008. Designing motivating jobs. Teoksessa Work Motivation: Past, Present, and Future. Toim. Kanfer, R., Chen, G. \& Pritchard, R. New York: Routledge, 233-384.

Schaufeli, W., 20I7. Applying the Job Demands-Resources model: A 'how to' guide to measuring and tackling work engagement and burnout. Organizational Dynamics, 46(2), I 20-I 32. Viitattu I 4. I. 202 I. https://doi.org/I0.1016/j.orgdyn.20I7.04.008

Tims, M., Bakker, A. \& Derks, D., 20 I 2. Development and validation of the job crafting scale. Journal of Vocational Behavior, 80(I), I73-186. Viitattu I 5. I. 202 I. https://doi. org/I0.10I6/j.jvb.20I I.05.009

Wrzesniewski, A., LoBuglio, N., Dutton, J., \& Berg, J., 2013. Job crafting and cultivating positive meaning and identity in work. Teoksessa Advances in positive organizational psychology, toim. Bakker, A. Emerald Group Publishing, 28 I-302.

\author{
ELINA KäHÖ \\ Helsingin yliopiston kirjasto \\ elina.kaho@helsinki.fi
}

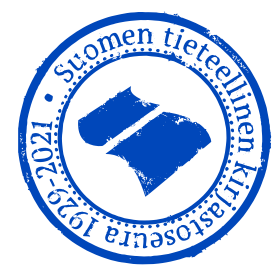

